\title{
Hepatoerythropoietic Porphyria
}

National Cancer Institute

\section{Source}

National Cancer Institute. Hepatoerythropoietic Porphyria. NCI Thesaurus. Code C84754.

A very rare form of porphyria cutanea tarda. It is characterized by deficiency of the enzyme uroporphyrinogen III. Signs and symptoms appear early in childhood and include extreme photosensitivity in the sun exposed areas of the skin with blistering and scar formation. 